\title{
Peer-Mentoring Program and Academic Atmosphere Towards Writing Achievement of the Students
}

\author{
Sri Endah Kusmartini (Corresponding author) \\ English Department, Sriwijaya State Polytechnic \\ Palembang - South Sumatera, Indonesia \\ E-mail: sriendahkusmartini@yahoo.com \\ Tiur Simanjuntak \\ English Department, Sriwijaya State Polytechnic \\ Palembang - South Sumatera, Indonesia \\ E-mail: tiur_simanjuntak@yahoo.com
}

Received: 07-10-2013

doi:10.7575/aiac.ijalel.v.3n.2p.83
Accepted: 06-12-2013

Published: 01-03-2014

URL: http://dx.doi.org/10.7575/aiac.ijalel.v.3n.2p.83

\begin{abstract}
Management of Sriwijaya State Polytechnic believes that peer-mentoring program has positive effects on students' academic success. Moreover, it is also believed that good academic atmosphere should be developed. In line with these, researchers tried to investigate whether peer-mentoring program and academic atmosphere correlated significantly to students' writing achievement partially and simultaneously. The research was conducted in English Department, Sriwijaya State Polytechnic with 60 samples taken randomly. Measures of Peer-mentoring Program and Academic Atmosphere were used sequentially to measure peer-mentoring program and academic atmosphere as perceived by the students. Meanwhile, writing score was used to find out writing achievement of the students. The hypotheses were tested by using Pearson Product Moment Correlation and Multiple Linear Regression. The results showed that peermentoring program and academic atmosphere as perceived by the students correlated significantly towards students' writing achievement partially and simultaneously. Therefore it is recommended to continue the programs.
\end{abstract}

Keywords: Peer-Mentoring Program, Academic Atmosphere, Writing Achievement

\section{Introduction}

Management of Sriwijaya State Polytechnic located in Palembang-South Sumatera Indonesia, has a great concern to the learning quality of the students (Politeknik Negeri Sriwijaya, 2013). Many efforts have been conducted to maintain the learning quality of the students. One of them is peer-mentoring program (Politeknik Negeri Sriwijaya, 2013). Upcraft (1989) mentions that peer-mentoring program can be a good intervention for the institution in order to develop the learning quality of the students and to improve the relationships with the teachers and the peers. This kind of intervention is getting popular among higher education systems nowadays (Rodger \& Tremblay, 2003). Ragins and Cotton (1999) mention that peer-mentoring program is good not only for mentee but also for mentor.

According to Bozeman and Feeney (2007), peer-mentoring program is a program which facilitates individual development relationship between peer-mentor with peer-mentee. Moreover, they mention that peer-mentor is a person who has more experience and is a more knowledgeable person, while peer-mentee is a person who has less experience and is a less knowledgeable person. Finally, they reveal that peer-mentor may challenge the peer-mentee with new ideas, and persuade the peer-mentee to experience new things comfortably.

Daloz (1990) explains that the meeting between peer-mentor and peer-mentee can vary from one time to three or four times a month depending on their particular mentoring program; the more the meeting, the better. However, Daloz (1990) suggests peer-mentor and peer-mentee to have more meeting in the beginning of the relationship in order to establish a good foundation. The contact between peer-mentor and peer-mentee can be via email, telephone or in-person (Daloz, 1990). To facilitate the program, Daloz (1990) suggests that peer-mentoring organization set up social events to provide good opportunities for peer-mentor and peer-mentee to increase their social interaction.

One of the educational goals of English Department, Sriwijaya State Polytechnic is the capability of the students to communicate by using written English language (Politeknik Negeri Sriwijaya, 2013). Therefore, the management decided to conduct peer-mentoring program to respond to this institutional need. The question arouse whether there is a significant correlation between peer-mentoring program as perceived by the students and their writing achievement or not. By recognizing the position of peer-mentoring program, the management understands whether to continue the program or not.

Another effort that has been conducted by the management in order to maintain the learning quality of the students is to create high-quality academic atmosphere. Lawrence and Vimala (2012) mention that environment has a very important role in the development of the students' qualities. Moreover, they also report that rural students feel school environment is very convenient for their studies. Therefore, appropriate and pleasant environment should be provided so that the effectiveness of learning can be obtained (Lawrence \& Vimala, 2012). The question also arouse whether there is a significant correlation between academic atmosphere as perceived by the students and their writing achievement or not. 
The research was very important so that the management can decide whether to continue the program of developing conducive academic atmosphere in Sriwijaya State Polytechnic especially in English Department or not. Finally, if peer-mentoring program is continued and at the same time academic atmosphere surrounding Sriwijaya State Polytechnic especially English Department is improved, then another question arouse whether peer-mentoring program and academic atmosphere correlated significantly to students' writing achievement partially and simultaneously. The research about the correlation of peer-mentoring program added to academic atmosphere towards writing achievement of the students was needed badly so that the management understands whether to continue the two programs or not.

Considering the commitment of the management to conduct peer-mentoring program and to maintain conducive academic atmosphere especially in English Department, State Polytechnic of Sriwijaya, the researchers tried to investigate whether there is a significant correlation between peer-mentoring program as perceived by the students and their writing achievement or not; whether there is a significant correlation between academic atmosphere as perceived by the students and their writing achievement or not; and whether peer-mentoring program added to academic atmosphere correlated significantly to students' writing achievement partially and simultaneously.

The current research tried to address the following research hypotheses. Ho1) Peer-mentoring program does not correlate significantly to writing achievement of the students; Ha1) Peer-mentoring program correlates significantly to writing achievement of the students; Ho2) Academic atmosphere does not correlate significantly to writing achievement of the students; Ha2) Academic atmosphere correlates significantly to writing achievement of the students; Ho3) Peermentoring program added to academic atmosphere does not correlate significantly to writing achievement of the students; Ha3) Peer-mentoring program added to academic atmosphere correlates significantly to writing achievement of the students.

\section{Methodology}

The following were the description of population and sample, instruments and materials, procedure, and research design.

\subsection{Population and Sample}

The population of this research was all students of English Department, Sriwijaya State Polytechnic in academic year of $2012 / 2013$. The number of the sample was 60 which were taken randomly.

\subsection{Instruments and Materials}

The researchers used a measure of Peer-mentoring Program $\left(\mathrm{PMP}_{\mathrm{S}}\right)$ to measure peer-mentoring program which was conducted in English Department, Sriwijaya State Polytechnic as perceived by their students. The questionnaire consists of two parts, namely demographic data and peer-mentoring program inventory which consisted of 23 items. The researchers also used a measure of Academic Atmosphere $\left(\mathrm{AA}_{\mathrm{S}}\right)$ which was originally conducted by McGhee, Lowell, and Lemire (2007) entitled the Classroom Learning Environment (CLE). In item categories of Classroom Learning Environment, the number of the item in the questionnaire was 46 in 8 categories; persistence in major, general positive, general negative, personal negative, values and beliefs, effort, other, and demographic. The researchers modified the questionnaire into a Measure of Academic Atmosphere with 27 items to measure academic atmosphere of English Department of Sriwijaya State Polytechnic based on the students' perception. The modification was conducted to suit with the condition of the students in Indonesia.

\subsection{Procedure}

The following were the procedure of obtaining the data. First, the researchers asked each respondent to fill in the demographic data including name, student's number, gender, class, and semester. Second, the researchers used a measure of Peer-mentoring Program $\left(\mathrm{PMP}_{\mathrm{S}}\right)$ to measure peer mentoring program as perceived by the students. The respondents were asked to determine the level of their agreement about the statements concerning peer-mentoring program by jotting down the suitable number ranges from 1 (strongly disagree) to 10 (strongly agree). The number of the items was 23 . The lowest possible score was 23 and the highest possible score was 230 . Third, the researchers used a measure of Academic Atmosphere $\left(\mathrm{AA}_{\mathrm{S}}\right)$ to measure academic atmosphere of the students. The respondents were asked to jot down the suitable number ranges from 1 (strongly disagree) to 10 (strongly agree) which showed the level of their agreement to the statements about academic atmosphere. The number of the items was 27 . The lowest possible score was 27 and the highest possible score was 270 . Fourth, the researchers got the data about the respondents' writing scores from the archive of English Department, Sriwijaya State Polytechnic. Finally, the researchers informed that the data taken from the whole respondents will be kept in strict confidence, and will only be used for academic purposes.

\subsection{Research design}

It was a correlational research. In this current research, the researchers used quantitative correlational design. The following was the paradigm.

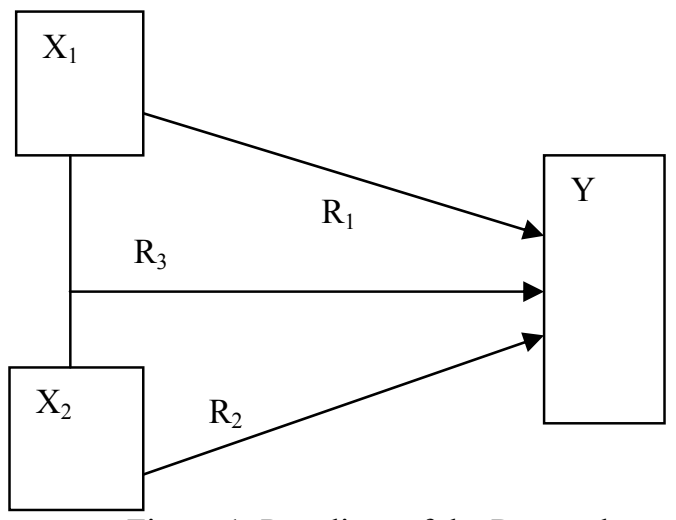

Figure 1. Paradigm of the Research 
$\mathrm{X}_{1}$ is the first independent variable, Peer-Mentoring Program as perceived by the students $\left(\mathrm{PMP}_{\mathrm{S}}\right) . \mathrm{X}_{2}$ is the second independent variable, Academic Atmosphere as perceived by the students $\left(\mathrm{AA}_{\mathrm{S}}\right)$. $\mathrm{Y}$ is dependent variable, Writing Achievement of the students $\left(\mathrm{WA}_{\mathrm{S}}\right)$. Pearson Product Moment Correlation was conducted to find out the correlation $\left(\mathrm{R}_{1}\right)$ between the first independent variable $\left(\mathrm{X}_{1}\right)$ and dependent variable $(\mathrm{Y})$. Pearson Product Moment Correlation was also conducted to find out the correlation $\left(\mathrm{R}_{2}\right)$ between the second independent variable $\left(\mathrm{X}_{2}\right)$ and dependent variable $(\mathrm{Y})$. Finally, Multiple Linear Regression was conducted to find out the correlation $\left(\mathrm{R}_{3}\right)$ between the first independent variable $\left(\mathrm{X}_{1}\right)$ added to the second independent variable $\left(\mathrm{X}_{2}\right)$ towards dependent variable $(\mathrm{Y})$; to find out the influence of the first independent variable $\left(\mathrm{X}_{1}\right)$ added to the second independent variable $\left(\mathrm{X}_{2}\right)$ towards dependent variable $(\mathrm{Y})$; and to find out the contribution of the first independent variable $\left(\mathrm{X}_{1}\right)$ added to the second independent variable $\left(\mathrm{X}_{2}\right)$ towards dependent variable (Y).

\section{Results}

The following were the frequency and the percentage of the variable of peer-mentoring program.

Table 1. Frequency and Percentage of the Variable of Peer-Mentoring Program

\begin{tabular}{lrlll}
\hline No. & Interval & Level of Agreement & Frequency & Percentage \\
\hline & & & & \\
1. & $23-74$ & strongly disagree & - & $0 \%$ \\
2. & $75-126$ & somewhat disagree & - & $0 \%$ \\
3. & $127-178$ & somewhat agree & 12 & $20 \%$ \\
4. & $179-230$ & strongly Agree & 48 & $80 \%$ \\
\hline
\end{tabular}

Based on the above table, it can be seen that on the average, there were no respondents $(0 \%)$ who strongly disagreed with the 23 items about peer-mentoring program; there were no respondents $(0 \%)$ who somewhat disagreed with the 23 items about peer-mentoring program; there were 12 respondents (20\%) who somewhat agreed with the 23 items about peer-mentoring program; and there were 48 respondents $(80 \%)$ who strongly agreed with the 23 items about peermentoring program.

The following were the frequency and the percentage of the variable of academic atmosphere.

Table 2. Frequency and Percentage of the Variable of Academic Atmosphere

\begin{tabular}{lrlcc}
\hline No. & Interval & Level of Agreement & Frequency & Percentage \\
\hline & & & & \\
1. & $27-87$ & strongly disagree & - & $0 \%$ \\
2. & $88-148$ & somewhat disagree & - & $0 \%$ \\
3. & $149-209$ & somewhat agree & 58 & $96.7 \%$ \\
4. & $210-270$ & strongly Agree & 2 & $3.3 \%$ \\
\hline
\end{tabular}

Based on the above table, it can be seen that on the average, there were no respondents $(0 \%)$ who strongly disagreed with the 27 items about academic atmosphere; there were no respondents $(0 \%)$ who somewhat disagreed with the 27 items about academic atmosphere; there were 58 respondents $(96.7 \%)$ who somewhat agreed with the 27 items about academic atmosphere; and there were 2 respondents $(3.3 \%)$ who strongly agreed with the 27 items about academic atmosphere.

The following were the frequency and the percentage of the variable of writing achievement.

Table 3. Frequency and Percentage of the Variable of Writing Achievement

\begin{tabular}{lllll}
\hline No. & Interval & Remark & Frequency & Percentage \\
\hline & & & & \\
1. & $<40$ & Fail & - & $0 \%$ \\
2. & $40-53$ & Poor & - & $0 \%$ \\
3. & $54-65$ & Fair & - & $0 \%$ \\
4. & $66-79$ & Good & 27 & $45 \%$ \\
5. & $80-100$ & Very good & 33 & $55 \%$ \\
\hline
\end{tabular}


Sriwijaya State Polytechnic (2013) categorized the students' score into five categories including Fail (for the score lower than 40), Poor (for the score from 40 to 53), Fair (for the score from 54 to 65), Good (for the score from 66 to 79) and Very good (for the score from 80 to 100). Based on the above table, it can be seen that there were no respondents $(0 \%)$ who failed in writing achievement; there were no respondents $(0 \%)$ who got poor score in writing achievement; there were no respondents $(0 \%)$ who got fair score in writing achievement; there were 27 respondents $(45 \%)$ who got good score in writing achievement; and there were 33 respondents $(55 \%)$ who got very good score in writing achievement

The following were the mean, minimum score and maximum score of peer-mentoring program as perceived by the students, academic atmosphere as perceived by the students, and writing achievement of the students.

Table 4. the Mean, Minimum Score and maximum Score of the Variables

\begin{tabular}{llccc}
\hline No. & Variable & Mean & Min. Score & Max. Score \\
\hline 1. & PMPs & 181.77 & 166 & 200 \\
2. & AA $_{S}$ & 179.63 & 150 & 229 \\
3. & WA $_{S}$ & 78.30 & 66 & 83 \\
\hline
\end{tabular}

Note:

$P M P_{S}=$ Peer-mentoring program as perceived by the students (the scale ranges from 23 to 230);

$A A_{S}=$ Academic Atmosphere as perceived by the students (the scale ranges from 27 to 270);

$W A_{S}=$ Writing Achievement of the students (writing scores) ranges from 0 to 100

The first variable was Peer-mentoring Program as perceived by the students $\left(\mathrm{PMP}_{\mathrm{S}}\right)$. Mean of the variable of Peermentoring Program as perceived by the students was 181.77. Minimum score of the variable was 166, and maximum score was 200. The second variable was Academic Atmosphere as perceived by the students $\left(\mathrm{AA}_{\mathrm{S}}\right)$. Mean of the variable of Academic Atmosphere as perceived by the students was 179.63. Minimum score of the variable was 150, and maximum score was 229. The last variable was Writing Achievement of the students $\left(\mathrm{WA}_{\mathrm{S}}\right.$ ). Mean of the variable of Writing Achievement of the students was 78.30. Minimum score of the variable was 66, and maximum score was 83 .

The following were the descriptions about the correlation between peer-mentoring program as perceived by the students $\left(\mathrm{PMP}_{\mathrm{S}}\right)$ and writing achievement of the students $\left(\mathrm{WA}_{\mathrm{S}}\right)$; and the correlation between academic atmosphere as perceived by the students $\left(A A_{S}\right)$ and writing achievement of the students $\left(W_{S}\right)$.

Table 5. Correlation between Two Variables

\begin{tabular}{lll}
\hline & & $\mathrm{WA}_{\mathrm{S}}$ \\
\hline PMP $_{\mathrm{S}}$ & Pearson Correlation & $.637^{* *}$ \\
& Sig. (2-tailed) & .000 \\
& $\mathrm{~N}$ & 60 \\
& & \\
\hline $\mathrm{AA}_{\mathrm{S}}$ & Pearson Correlation & $.365^{* *}$ \\
& Sig. (2-tailed) & .004 \\
& $\mathrm{~N}$ & 60 \\
& & \\
$* *$ Correlation is significant at the 0.01level (2-tailed) &
\end{tabular}

The correlation between peer-mentoring program as perceived by the students and writing achievement of the students was 0.637 with probability value 0.000 which was lower than the alpha level $(0.000<0.01)$. Therefore, $\mathrm{Ho}_{1}$ was rejected and $\mathrm{Ha}_{1}$ was accepted. It can be concluded that there was a significant correlation between Peer-mentoring Program as perceived by the students and writing achievement of the students. The correlation between Academic Atmosphere as perceived by the students and writing achievement of the students was 0.365 with probability value 0.004 which was lower than the alpha level $(0.004<0.01)$. Therefore, Ho2 was rejected and Ha2 was accepted. It can be concluded that there was a significant correlation between Academic Atmosphere as perceived by the students and writing achievement of the students.

The following were the description about the correlation, the influence and contribution of Peer-mentoring Program as perceived by the students added to Academic Atmosphere as perceived by the students towards writing achievement of the students. 
Table 6. Correlation, Influence and Contribution

Model Summary ${ }^{\mathrm{b}}$

Model R R Square

1

$.669^{\mathrm{a}}$

.448

a. Predictors: (Constant), Academic Atmosphere as Perceived by the Students, Peer-mentoring Program as Perceived by the Students

b. Dependent Variable: Writing Achievement of the Students

\begin{tabular}{lllllll} 
ANOVA $^{\mathrm{b}}$ & \multicolumn{1}{l}{} & & & \\
\hline Model & & $\begin{array}{l}\text { Sum of } \\
\text { Squares }\end{array}$ & df & Mean Square & F & Sig. \\
\hline 1 & $\begin{array}{llllll}\text { Regression } \\
\text { Residual } \\
\text { Total }\end{array}$ & 290.451 & 2 & 145.226 & 23.113 & $.000^{\mathrm{a}}$ \\
& 358.149 & 57 & 6.283 & & \\
& 648.600 & 59 & & & \\
\end{tabular}

a. Predictors: (Constant), Academic Atmosphere as Perceived by the Students, Peer-mentoring Program as Perceived by the Students

b. Dependent Variable: Writing Achievement of the Students

The above table showed that the correlation of Peer-mentoring Program as perceived by the students $\left(\mathrm{PMP}_{\mathrm{S}}\right)$ added to Academic Atmosphere as perceived by the students $\left(\mathrm{AA}_{\mathrm{S}}\right)$ towards Writing Achievement of the students (WA $)$ was 0.669. Sugiyono (2008) mentions that interval coefficient between 0.000 to 0.199 means that the level of correlation is very weak; interval coefficient between 0.200 to 0.399 means that the level of correlation is weak; interval coefficient between 0.400 to 0.599 means that the level of correlation is fair; interval coefficient between 0.600 to 0.799 means that the level of correlation is strong; and interval coefficient between 0.800 to 1.000 means that the level of correlation is very strong. The correlation of 0.637 between peer-mentoring program as perceived by the students and writing achievement of the students means that their correlation was strong. The correlation of 0.365 between academic atmosphere as perceived by the students and writing achievement of the students means that the correlation between them was weak. The correlation of 0.669 between peer-mentoring program as perceived by the students added to academic atmosphere as perceived by the students towards students' writing achievement means that the correlation was strong.

Next, the above table also showed that $\mathrm{R}$ square $\left(\mathrm{R}^{2}\right)$ of Peer-mentoring Program as perceived by the students $(\mathrm{PMP})$ added to Academic Atmosphere as perceived by the students $\left(\mathrm{AA}_{\mathrm{S}}\right)$ towards Writing Achievement of the students $\left(\mathrm{WA}_{\mathrm{S}}\right.$ ) was 0.448 . It showed the influence of Peer-mentoring Program as perceived by the students added to Academic Atmosphere as perceived by the students towards Writing Achievement of the students was 0.448. Moreover, it also showed that the contribution of Peer-mentoring Program as perceived by the students $\left(\mathrm{PMP}_{\mathrm{S}}\right)$ added to Academic Atmosphere as perceived by the students $\left(\mathrm{AA}_{\mathrm{S}}\right)$ towards Writing Achievement of the students $(\mathrm{WA})$ was $44.8 \%$. In this case, unexplained factor was $55.2 \%(100 \%-44.8 \%)$.

Finally, the above table also showed that $\mathrm{F}$ obtain was 23.113 which was bigger than $\mathrm{F}$ table $(23.113>3.159)$ with probability value 0.000 which was smaller than the alpha level $(0.000<0.05)$. It means that Peer-mentoring Program as perceived by the students added to Academic Atmosphere as perceived by the students influenced Writing Achievement of the students significantly. Therefore $\mathrm{Ho}_{3}$ was rejected and $\mathrm{Ha}_{3}$ was accepted. Peer-mentoring program added to academic atmosphere correlates significantly to writing achievement of the students.

\section{Discussion}

The positive significant correlation found between peer-mentoring program as perceived by the students and writing achievement of the students suggests that the better the peer-mentoring program applied, the higher the writing achievement of the students.

The positive significant correlation found between academic atmosphere as perceived by the students and writing achievement of the students suggests that the better the academic atmosphere applied, the higher the writing achievement of the students.

The positive significant correlation found between peer-mentoring program as perceived by the students added to academic atmosphere as perceived by the students towards writing achievement of the students suggests that the better the peer-mentoring program and academic atmosphere applied simultaneously, the higher the writing achievement of the students. 
The strong correlation $(\mathrm{R}=0.637)$ between peer-mentoring program as perceived by the students and writing achievement of the students suggests that everyone involves in maintaining the learning quality of the students should consider the variable of peer-mentoring program as one of important aspects in maintaining the learning quality of the students.

Even though the correlation between academic atmosphere as perceived by the students and writing achievement of the students was weak $(\mathrm{R}=0.365)$, however, the correlation was significant. It means that everyone involves in maintaining the learning quality of the students should consider this variable too.

The strong correlation $(\mathrm{R}=0.669)$ between peer-mentoring program as perceived by the students added to academic atmosphere as perceived by the students towards students' writing achievement suggests that everyone involves in maintaining the learning quality of the students should consider these both variables.

The fact that Peer-Mentoring Program as perceived by the students added to Academic Atmosphere as perceived by the students contributes significantly towards Writing Achievement of the students suggests that in order to develop the writing achievement of the students, it is important to involve the variable of Peer-Mentoring Program and the variable of Academic Atmosphere simultaneously.

The contribution of $44.8 \%$ of the variable of Peer-Mentoring Program added to the variable of Academic Atmosphere towards Writing Achievement of the students suggests that $55.2 \%$ of the variance in Writing Achievement of the students were contributed by unexplained factors.

\subsection{Limitations}

This current research was a quantitative correlational research. This kind of research only described the variables statistically, answered yes/no questions, and proved null and alternative hypotheses. It could not answer the questions why peer-mentoring program added to academic atmosphere correlated significantly towards writing achievement of the students partially and simultaneously. Moreover, this current research could not answer the question how peermentoring program added to academic atmosphere correlated significantly towards writing achievement of the students like in qualitative research.

\subsection{Suggestions for Future Studies}

Future studies are suggested to investigate why and how peer-mentoring program added to academic atmosphere correlates significantly towards writing achievement of the students by using qualitative research. Furthermore, it is suggested that the future studies investigate unexplained factors, those which were not investigated in this current research.

\section{Conclusion}

Based on the above results and discussion, it can be concluded that there was a significant correlation between peermentoring program as perceived by the students and writing achievement of the students; there was a significant correlation between academic atmosphere as perceived by the students and writing achievement of the students; and the correlation of peer-mentoring program as perceived by the students added to academic atmosphere as perceived by the students towards writing achievement of the students was significant. Peer-mentoring program as perceived by the students added to academic atmosphere as perceived by the students influenced writing achievement of the students significantly and gave $44.8 \%$ contribution. Therefore, it is recommended that Sriwijaya State Polytechnic especially English Department to continue the programs.

\section{References}

Bozeman, B. \& Feeney, M. K. (2007). Towards a useful theory of mentoring: A conceptual analysis and critique. Administration \& Society, 39(6), 719-739.

Daloz, L. A. (1990). Effective teaching and mentoring. San Francisco: Jossey- Bass.

Lawrence, A. S. A. \& Vimala, A. (2012). School environment and academic achievement of standard IX students. Journal of Educational and Instructional Studies in the World, 2(3), 210-215.

McGhee, D. E., Lowell, N. \& Lemire, S. (2007). The classroom learning environment (CLE) questionnaire: Preliminary development. University of Washington Office of Educational Assessment.

Politeknik Negeri Sriwijaya (2013). Buku pedoman Politeknik Negeri Sriwijaya. Palembang

Ragins, B. R. \& Cotton, J. L. (1999). Mentor functions and outcomes: A comparison of men and women in formal and informal mentoring relationships. Journal of Applied Psychology, 84(4), 529-550.

Rodger, S. \& Tremblay, P. F. (2003). The effects of a peer mentoring program on academic success among first year university students. The Canadian Journal of Higher Education, 33(3), 1-17.

Sugiyono. (2008). Metode penelitian bisnis (pendekatan kuantitatif, kualitatif dan $R \& D$ ). Penerbit Alfabeta, Bandung. Upcraft, M. L. (1989). The freshman year experience: Helping students survive and succeed in college. San Francisco, CA: Jossey-Bass. 